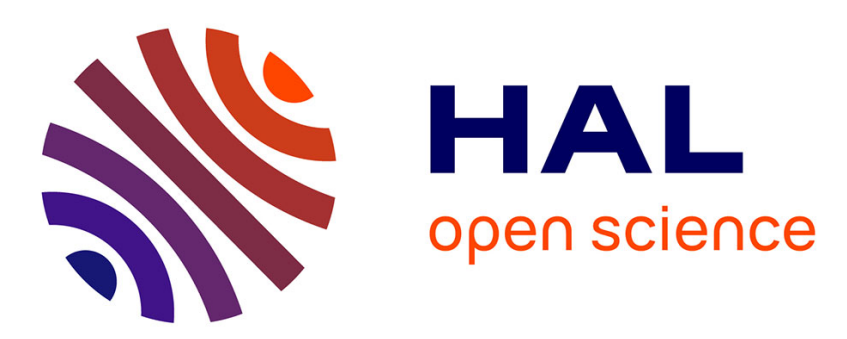

\title{
Impact of weathering on macro-mechanical properties of chalks
}

Christophe Auvray, Noémie Lafrance, Mountaka Souley, Vincent Labiouse

\section{To cite this version:}

Christophe Auvray, Noémie Lafrance, Mountaka Souley, Vincent Labiouse. Impact of weathering on macro-mechanical properties of chalks. International Symposium of ISRM "Rock Mechanics and Rock Engineering: From the Past to the Future" (EUROCK 2016), Aug 2016, Cappadocia, Turkey. pp.885-890. ineris-01854305

\section{HAL Id: ineris-01854305 \\ https://hal-ineris.archives-ouvertes.fr/ineris-01854305}

Submitted on 4 Sep 2018

HAL is a multi-disciplinary open access archive for the deposit and dissemination of scientific research documents, whether they are published or not. The documents may come from teaching and research institutions in France or abroad, or from public or private research centers.
L'archive ouverte pluridisciplinaire HAL, est destinée au dépôt et à la diffusion de documents scientifiques de niveau recherche, publiés ou non, émanant des établissements d'enseignement et de recherche français ou étrangers, des laboratoires publics ou privés. 


\title{
Impact of weathering on macro-mechanical properties of chalks
}

\author{
C. Auvray \& N. Lafrance \\ Université de Lorraine, CNRS, CREGU, GeoRessources Laboratory, Vandoeuvre-Lès-Nancy, France \\ M. Souley \\ INERIS, clo Ecole des Mines de Nancy, Campus ARTEM, CS, Nancy, France \\ V. Labiouse \\ Haute Ecole d'Ingénierie et d'Architecture de Fribourg HEIA-FR - HES-SO, CP, Fribourg, Switzerland
}

\begin{abstract}
Chalk has long been used as a strong building material. The shallow underground room-andpillar quarries where the chalk was extracted now lie abandoned and endure the effects of time and weathering, increasing their risk of collapse. The risk of instability is an issue for more than 10000 towns in France. We have studied the physico-mechanical behaviour and ageing of two types of chalk in underground quarries in the Parisian Basin, France. The dolomitic chalk (Saint-Martin-Le-Noud) exhibits variations in mechanical and physical properties with horizontal pillar depth, and both density and compressive strength appear to increase outwards from the core to the wall of the pillar. SEM analysis reveals progressive degradation and increasing homogeneity of the grains from the edge to the inside of the pillar. In contrast, in physico-mechanical tests and SEM analyses performed on the Estreux glauconitic chalk, no significant variation was observed between the pillar wall and pillar core.
\end{abstract}

\section{INTRODUCTION}

Alteration can be defined as a modification of the physico-chemical properties of minerals and therefore rocks, by atmospheric agents, groundwater or thermal waters (Foucault \& Raoult 1995). The process is dependent on climate, water and temperature, as well as on the nature and degree of fissuring of the rock. Alteration generally leads to less-coherent rocks, promoting their deterioration and eventual failure (Gupta \& Seshagiri Rao 2000, Massuda 2001). Macroscopic signs of alteration include the appearance of cracks, microfractures and macroporosity, as well as the presence of hard deposits that result from chemical transformations (Oyama \& Chigira 2000). The alteration of rocks by dissolution (limestones, tuffs, sandstones, crystalline rocks), with or without mineral neoformation, has been studied by numerous authors (Gupta \& Seshagiri Rao 2000).

The term "ageing" refers to weathering of a rock within a medium influenced by human activity. In the context of underground structures, the term is used to describe the range of mineralogical and physical modifications of the rock over time. These modifications then lead to a deterioration of the hydraulic or mechanical properties.

The effect of time on the behaviour of an unlined underground structure encompasses various phenomena responsible for the variations in the material properties: (i) degradation of minerals in the rock as a result of physico-chemical action, leading to a reduction in the mechanical characteristics; (ii) differed deformation due to constant loading; (iii) variations in humidity (often linked to the airing conditions in the underground quarry) and thus in the saturation and suction conditions that affect the rock mass, over time. These cyclical variations in the hydric boundary conditions may generate damage due to hydro-mechanical coupling.

The influence of all of these phenomena must be taken into account when studying the temporal evolution of underground quarries, with the aim of being able to provide optimum remediation strategies for ensuring the long-term stability of the quarries with regards to public safety and the protection of built resources.

In the present study, we restrict our assessment of ageing to two types of chalk sampled in two different underground quarries. Following a short description of the quarries and sampling methodology employed, the scanning electron microscope (SEM) observations of the chalk samples are discussed in detail. The trends in a number of physico-mechanical parameters (porosity accessible to water, water content, density and uniaxial compressive strength) are then highlighted. 


\section{DESCRIPTION OF THE UNDERGROUND QUARRIES}

Chalk is an easily-crafted material that has been used for centuries in building and construction. The shallow underground room-and-pillar quarries where the chalk rocks were extracted have since been abandoned and now endure the effects of time and weathering, potentially increasing their risk of collapse. In order to prevent this risk, the "Institut National de l'Environnement Industriel et des Risques" (INERIS) has been studying the behaviour of the rock in two partially flooded underground chalk quarries, subject to water table fluctuations, at Estreux (EX) and StMartin-Le-Nœud (SM) in northern France (Gombert et al. 2013). These quarries, located at an average depth of 20 to $25 \mathrm{~m}$, were exploited by the room and pillar method, with an extraction rate of $60-75 \%$. The quarries were abandoned over a century ago. In situ instrumentation was implemented in these quarries in 2004 and 2009, with the aim of determining the impact of water-table fluctuations on their stability. These fluctuations lead to chemical interactions between the chalk and the water, thereby affecting the mechanical behaviour of the chalk through changes in the weathering conditions (Talesnick et al. 2001, Schroeder 2002, 2003, Risnes et al. 2003, 2005, Duperret et al. 2005, Nguyen 2010, Gombert et al. 2013, Lafrance et al. 2014). Preliminary laboratory characterization (e.g., mineralogical studies and uniaxial and triaxial compression tests) has also been undertaken (Gombert et al. 2013, Lafrance et al. 2014). Nevertheless, the hydro-chemo-mechanical behaviour of the chalk remains poorly understood due to complex interlocking phenomena that act on the mechanical behaviour of chalk. It therefore remains necessary to address this issue in the framework of multi-scale (SEM, laboratory and in situ scales) and multi-physics (mechanic, hydraulic and chemical) approaches.

The Saint-Martin-le-Nœud underground quarry (SM) is located on a hillside to the south of Beauvais (Oise, Picardie, France). The chalk was quarried by the room-and-pillar method, leaving behind galleries of between 3 and $5 \mathrm{~m}$ width, originally $4 \mathrm{~m}$ in height, and irregular pillars of between 2 and $4 \mathrm{~m}$ width. The estimated rate of extraction is $50 \%$ to $67 \%$ (Gombert et al. 2013). Based on the overlying rock thickness $(25 \mathrm{~m})$, the average vertical stress in the pillars is about 1 to $1.5 \mathrm{MPa}$. The stratigraphy of SM has a near-tabular profile with a gentle dip $\left(\approx 4-10^{\circ}\right)$. Due to this shallow dip, the deepest parts of the underground quarry reach the shallow aquifer, resulting in the formation of several "underground lakes". The Santonian-age chalk is notable for its relatively high dolomite content (14\%). The average porosity is about $42 \%$, with a tight range of pore-size distribution.

The Estreux underground quarry (EX) is located in the town of Saint-Saulve, close to the city of Valenciennes in northern France. A total surface area of approximately $10^{5} \mathrm{~m}^{2}$ has been excavated in underground quarries that date from the 19th century. The quarry has been abandoned for more than a century.
Like the SM underground quarry, the EX quarry was exploited by the room-and-pillar method and contains galleries of $1.5-$ to $2-\mathrm{m}$ width supported by rectangular pillars measuring 1.5 to $4 \mathrm{~m}$ from side to side (rate of extraction $\approx 78 \%$, overlying rock thickness $\approx 20 \mathrm{~m}$, estimated vertical stress $\approx 1.8 \mathrm{MPa}$; Nguyen 2010). Backfilling of the entire exploited area with mining waste has resulted in a lowering of the height of the gallery, from an initial height of three meters to its present height of two meters. The stratigraphy has a tabular profile. The Turonian-age chalk contains a relatively high amount (24\%) of glauconite, a clay mineral of the muscovite family, and is not as homogenous as the dolomitic chalk in terms of its structure. The porosity is around $35 \%$ and displays a tight range of pore-size distribution.

Chalk samples were collected from both sites by drilling $120-\mathrm{mm}$ diameter, $2 \mathrm{~m}$ long boreholes horizontally into the pillars. Cylindrical plugs $(20 \mathrm{~mm}$ diameter, $40 \mathrm{~mm}$ height) were taken from each of the cores at intervals of approximately $10 \mathrm{~cm}$. The longitudinal axis of each plug sample is therefore parallel to the axis of the pillar. The same sampling approach has been successfully applied to gypsum and iron ore in previous studies (Auvray et al. 2004, Grgic et al. 2001, Grgic et al. 2013).

\section{SCANNING ELECTRON MICROSCOPE OBSERVATIONS}

Samples from both quarries were examined by scanning electron microscopy (SEM). In the SM chalk, structural differences were observed between samples collected from the pillar-walls and those taken from the middle of the pillars. At the pillar walls, we observed euhedral crystals of 5 to 10 microns in size micro-calcite that presented no signs of neoprecipitation (Fig. 1a). In contrast, crystals at the centre of the pillars were micro- to submicron-sized in size and xenomorphic (anhedral) (Fig. 1e), probably due to partial dissolution. It was not possible to identify any particular zoning of these differences; both the decrease in crystal size and the change from euhedral to anhedral crystal shape appeared to be continuous from the walls to the centres of the pillars. It was not possible to distinguish or measure the dimensions of any dissolution fringe.

In contrast to the EX chalk, no variation in crystal size with horizontal core-depth was observed in the Estreux chalk pillars. A number of crystals in each sample plug exhibited clear dissolution marks (Figs. If and $1 \mathrm{j})$.

\section{PHYSICO- MECHANICAL} CHARACTERIZATIONS

Different physical and mechanical parameters were determined for all cores of up to $2 \mathrm{~m}$ length: rock density (dry and at saturation) ( $\rho \mathrm{dry} / \rho$ sat); porosity 

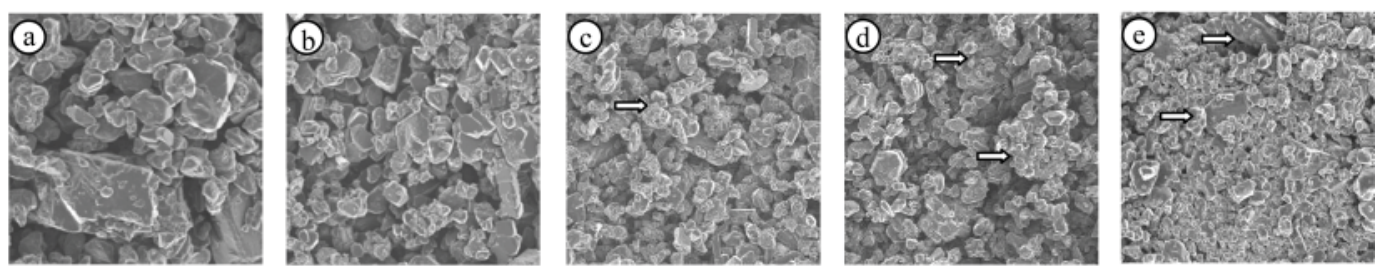

Wall

Horizontal coring - ESTREUX

Middle of pillar
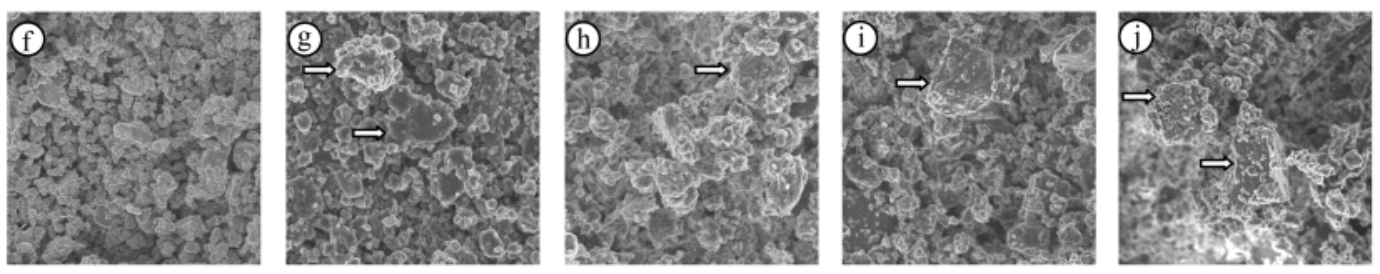

Figure 1. Structural and morphological variations $(\Rightarrow$ : dissolution marks) in the Saint-Martin-Le-Nœud and Estreux chalks.
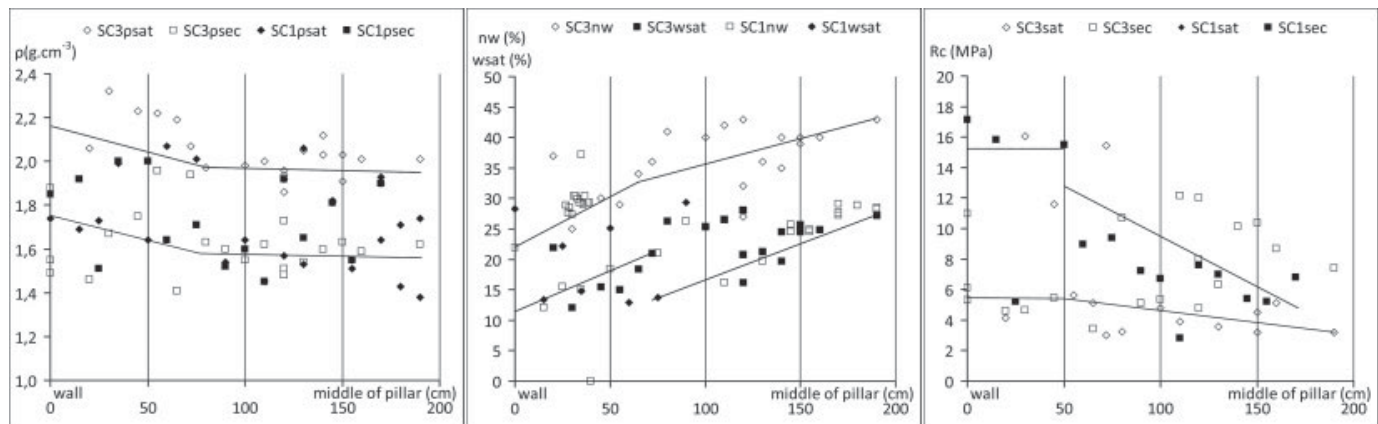

Figure 2. Variations in physico-mechanical parameters with horizontal core-depth (SCx: horizontal core, nw: porosity accessible to water, w: water content, $\rho$ : density, Rc: uniaxial compressive strength, sat: in a saturated state, sec: in a dry state) in the Saint-Martin-Le-Nœud chalk.

accessible to water (nw); water content at saturation (Wsat); and uniaxial compressive strength under dry/saturated conditions (Rcdry/Rcsat). The water used to saturate the samples was saturated (in terms of calcite) prior to the experiments in order to avoid any dissolution of the rock. The compression tests were performed using a hydraulic press of $5 \mathrm{kN}$ capacity. Some internal variation was observed in the data acquired from laboratory tests performed under dry and saturated conditions, however a discussion of these variations is beyond the scope of our study. We can nevertheless discuss the main variations observed in the physico-mechanical properties of the chalk with horizontal core-depth.

The results of the tests performed on samples from the SM underground quarry are presented in Figure 2: (i) the observed variations in the four physical properties (densities, water content and porosity) clearly indicate the existence of two distinct domains in the pillars: one between the wall and a depth of $75 \mathrm{~cm}$, and the second from a depth of $75 \mathrm{~cm}$ to the middle of pillar. In the outer domain, wet and dry densities decrease with depth while the wateraccessible porosity and water content increase. In the inner domain, despite some internal variation, the physical properties generally appear to form plateaus; (ii) in terms of the mechanical properties (uniaxial compressive strength in saturated and dry conditions), two domains of variation can again be identified in the pillars but the boundary between them occurs at $50 \mathrm{~cm}$ horizontal depth rather than at $75 \mathrm{~cm}$. In the outer domain, uniaxial compressive strength does not vary and can be considered constant. Approximately the same mean value was obtained for both dry and 


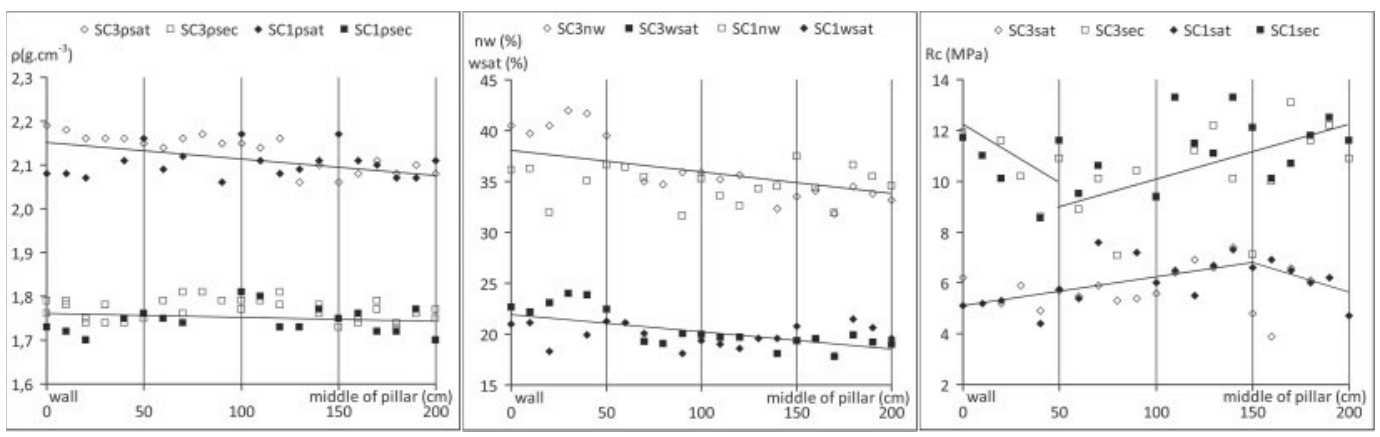

Figure 3. Variations in physico-mechanical parameters with horizontal core-depth (SCx: horizontal core, nw: porosity accessible to water, w: water content, $\rho$ : density, Rc: uniaxial compressive strength, sat: in a saturated state, sec: in a dry state) in the Estreux chalk.

saturated states. In the second (innermost) domain, the dry uniaxial compressive strength increases with depth whereas the strength under saturated conditions forms a plateau with a value that is $2-3$ times lower than that obtained at the edge of the pillar (in the outer domain). Thus, a significant drop in saturated uniaxial compressive strength occurs at the transition between the two domains.

Results for the tests on samples from the EX underground quarry are presented in Figure 3: (i) the trends in the physical and mechanical properties of the EX chalk are all continuous with core-depth. (ii) the resistance of dry and saturated samples under uniaxial compression shows some variation, but there is no clear overall trend with core depth. However, the variation in uniaxial compressive strength is identical to that seen in the second domain of the SM chalk, i.e., increasing from the wall to the middle of pillar in the dry state and forming a near-plateau in saturated uniaxial compressive strength; (iii) overall, the trends are more clearly defined in the EX chalk than they are in the SM chalk, but the main variations are of smaller magnitude at EX.

\section{INTERPRETATION \& DISCUSSION}

In the chalk from the EX underground quarry, the intensity of the traces of dissolution does not vary along the length of the core (Lafrance et al. 2014), however the porosity accessible to water decreases from the pillar wall to the middle of the pillar. Water (vapour and/or liquid) will progressively dissolve crystals and penetrate a pillar towards its centre. An increase in porosity accessible to water is therefore a direct effect of dissolution. Consequently, the amount of empty space, such as cracks and pores, should be greater at the pillar walls than in the middle of the pillars. From the SEM observations (Fig. 1), these empty spaces appear to be in the form of dissolution cavities. The dissolution does not appear to be zoned, however, and in fact, the entire pillar appears to have experienced partial dissolution. According to these hypotheses then, the strength of the material should increase towards the centre of a pillar (the edges of the pillars being more damaged than their centres and being composed of more porous material). However, the data obtained from the uniaxial compression tests suggest that the strength of the chalk is in fact highly variable, masking any correlation with core depth if it does indeed exist. It is possible that the anthropogenic changes, synonymous with ageing, are too advanced in these pillars to allow either a dissolution fringe or progressive degradation to be distinguished. Investigation of samples from a longer, horizontal borehole drilled into the rock face could shed further light on this.

In the SM underground quarry samples, no dissolution marks were observed at the edges of the pillar at the scale of our observations (Lafrance et al. 2014), but dissolution marks become increasingly visible towards the centres of the pillars. In addition, a large decrease in the size of calcite crystals was observed from the edge to the centre of the pillar. However, the explanation put forward for the EX chalk does not hold for the SM chalk. Even though the density of the rock decreases from the pillar wall to its centre, the other parameters - water-accessible porosity, water content at saturation and strength under uniaxial compression in saturated conditions - all show an overall decrease towards the centre of the pillars. In other words, the centres of the pillars appear to be more damaged than their walls.

In an attempt to explain these variations, a number of hypotheses can be put forward. Sorted by their reaction rate, these include (in descending order): (i) vertical drainage that is greater down the interior of the pillar than down its edges; (ii) aggrading neomorphism or Ostwald ripening; (iii) an oxidizing environment, which would favour recrystallization at the pillar edges:

i) Vertical drainage through the pillar:

Barhoum (2014) demonstrated that a significant proportion of the water circulation in the SM quarry study area takes place vertically. The pillars therefore appear to act as giant stalactites (Gombert 2014). Stalactites are formed by the crystallization of rings of calcium carbonate towards the exterior 
during carbon dioxide outgassing, forming a tube through which water can percolate. Crystallization around the pillar edges is therefore feasible. As well as playing a role in chemical weathering via dissolution, water also plays a part in erosion. The dissolved ion content of the percolating waters is usually equal to or lower than that of the lake waters. Because the core of the pillar is in a permanent state of saturation, oversaturation/oxidation of the environment does not occur. As the residence times of fluids (a mixture of primarily percolating water and underground lake water (Barhoum 2014) are longer in the centre of the pillar than at its edges, the loading surface of the crystals will change in the presence of crystals, and dissolution as well as particle transport will dominate over crystallization.

ii) Aggrading neomorphism (Ostwald Ripening):

In the SM chalk, the largest crystals at the edges are well-formed rhombohedra, very different in form and size from the minute calcite shells encountered in the chalk. No dissolution cavities were observed in these large crystals whereas some were observed in the smaller crystals. The fact that dissolution marks are present in the small crystals but not in the large crystals suggests that the latter are more stable and more resistant to dissolution. This discrimination between crystal size is characteristic of aggrading neomorphoism or the Ostwald 'ripening' phenomenon, which is driven by differences in surface energy (Ratke \& Vorhees, 2002; Voorhees \& Glicksman, 1984). Ostwald ripening is a spontaneous process in which minute solid particles evolve through time in a lightly oversaturated liquid. The grains all have the same chemical composition but differ in size. The ripening process is driven by the dependence of the solubility of a crystal on crystal size, and is expressed by the Gibbs-Kelvin relationship. The SM quarry is situated directly at the level of the water table (or unsaturated zone) (Barhoum 2014) and waters derived from the lakes that have formed around the pillar are in chemical equilibrium with the calcite, at a $\mathrm{pH}$ level of around 7.30. The edges of the chalk pillars are therefore subject to quite frequent wetting/drying cycles, which are largely synchronous with fluctuations in the water table (Gombert 2014).

iii) Evolution in an oxidising environment predisposed to recrystallization:

Of the different accessory minerals found in chalk, silica, like clay, has a tendency to inhibit the dissolution/recrystallization of calcite, which is in equilibrium at a $\mathrm{pH}$ of around 8.0.

The pillar in the underground quarry at SM, appears to have evolved in an oxidising environment. The $\mathrm{pH}$ is stable at around 7.30 (and does not vary over the course of the year; Barhoum 2014) and, like for hydrogen carbonates, the water is saturated in oxygen in a cyclical manner according to the period of the year. However, sufficiently oxidising conditions in the chalk will lead to the breakdown of organic matter and the clearing of crystal growth sites. Recrystallization will take place once a site is completely free of organic matter and the environment is enriched in calcium and hydrogen carbonate ions (Belova and al. 2012, Robinson \& Woodun 2008). The oxidising properties, the cyclical oversaturation (via fluctuations in the water table) and the chemistry of the water, together represent a set of conditions that are particularly favourable to the recrystallization of calcite at the edge of a pillar. Such conditions do not appear to exist at the core of the pillars, which are continually saturated (see the following section).

The chalk at EX exhibits traces of dissolution but no recrystallization (according to the SEM images). The $\mathrm{pH}$ of the groundwater in the surrounding area is clearly lower than that required for calcite equilibrium and is therefore potentially oxidizing. However, the chalk also contains a relatively high amount of glauconite (a green ferrous alteration mineral that forms in a reducing environment during diagenesis) which will act as a reducing agent. If the reduction potential is greater than the oxidation potential, as seems to be the case here, then the environment will remain in a reducing state and the clay matter will retain its role as an inhibitor of recrystallization and have a buffering effect on the oxidising properties of the water. However, because the $\mathrm{pH}$ is lower than the equilibrium $\mathrm{pH}$ of the calcite, the calco-carbonic equilibrium is displaced and dissolution marks may begin to appear.

Any one of these mechanisms, or indeed a combination of two or all three, may explain the observed decrease in the physical and mechanical properties of the rock towards the centres of the Saint-Martin pillars. Elsewhere, a dataset comprising measurements of resistance under compression for horizontal boreholes drilled into a phosphate chalk underground quarry at Malogne at Cuesmes, near Mons in Belgium (Funcken $\&$ Welter 1996) is currently available. The resistance values measured in the Malogne chalk appear to decrease towards the interior of the pillar. This supports the findings of our study and allows us to favour the hypothesis of preferential vertical drainage down the middle of a pillar. It also suggests that the trend shown for SM underground quarry is not merely an isolated case.

\section{CONCLUSION}

Evidence for temporal changes to chalk in underground quarries where human activity has long ceased, which can be interpreted as ageing, are observed at the underground quarry at SM. The density and intensity of dissolution marks in calcite grains appears to decrease outwards from the inner-core of the pillar towards the pillar walls. However, rock density decreases in the opposite direction, from the wall towards the centre, and parameters such as wateraccessible porosity, water content at saturation, resistance to uniaxial compression under saturated conditions also present an overall decrease from the wall towards the middle of the pillars. Three hypotheses, 
sorted by their reaction rate in descending order, can be put forward to explain the observed variations: (i) vertical drainage that is greater down the interior of the pillar than down its edges; (ii) aggrading neomorphism or Ostwald ripening; (iii) an oxidising environment which favours recrystallization at the pillar edges.

At the Estreux site, the ageing of the glauconitic chalk already appears to be at an advanced stage. The level of uniformity in the data suggests that there is currently no intermediate stage between a 'healthy' and an aged state (with dissolution marks). This may explain why we were unable to distinguish any zoning of either dissolution marks or resistance to uniaxial compression.

\section{REFERENCES}

Auvray, C., Homand, F. \& Sorgi, C. 2004. The ageing of gypsum in underground mines. Engineering Geology, 74: 183-196.

Barhoum, S. 2014. Transferts dans la craie. Approche locale: la carrière de Saint-Martin-le-Nœud. Approche régionale: le Nord-Ouest du Bassin de Paris. PhD thesis, UPMC France.

Belova, D.A., Johnsson, A., Bovet, N., Lakshtanov, L.Z. \& Stipp, S.L.S. 2012. The effect on chalk recrystallization after treatment with oxidizing agents. Chemical Geology, 291: 217-223.

Brignoli, M., Righetti, C. \& Santarelli, F.J. 1994. Capillary phenomena in an impure chalk.SPE/IRSM 28135, Proc. EUROCK '94 Rock Mechanics in Petroleum Engineering, Delft, 837-844.

Duperret, A., Taibi, S., Mortimore, R.N. \& Daigneault, M. 2005. Effect of groundwater and sea weathering cycles on the strength of chalk rock from unstable coastal cliffs of NW France. Engineering Geology, 78: 321-343

Foucault, A. \& Raoult, J.F. 1995. Dictionnaire de géologie Ed. Masson, 4ème édition, 326.

Funcken, L. \& Welter, Ph. 1996. Procès verbal-Stabilité de la carrière de la Malogne (Mons, Belgique), 38.

Gombert, P., Auvray, C. \& Al Heib, M. 2013. In-situ and laboratory tests to evaluate the impact of water table fluctuations on stability of underground chalk mines. Procedia Earth and Planetary Science, 7: 304-308.

Gombert, P. 2014. Bilan des études et travaux réalisés dans les carrières souterraines de craie de Saint-Martin-le-Nœud (60) et d'Estreux (59). Programme EAT-DRS-02. INERISDRS-14-141876-1199A

Grgic, D., Homand, F. \& Dagallier, G. 2001. Ageing of Lorraine (France) abandoned iron mines. Rock Mechanics: a challenge for society. ISRM Reg EUROCK Symposium on Rock Mechanics. Espoo, Finland. June 04-07. 825-830.
Grgic, D., Giraud, A. \& Auvray, C. 2013. Impact of chemical weathering on micro/macro-mechanical properties of oolithic iron ore. Int. J. of Rock Mech. \& Min. Sc., 6(4): 236-245.

Gupta, A.S. \& Seshagiri Rao, K. 2000. Weathering effects on the strength and deformational behaviour of crystalline rocks under uniaxial compression state. Engineering Geology, 56: 257-274.

Lafrance, N., Auvray, C., Souley, M., Favreau, O. \& Labiouse, V. 2014. Ageing of chalk rocks in an underground quarry. IRSM International Symposium Eurock Vigo, Spain, 445-450.

Nguyen, H.D. 2010. Influence des interactions eau-roche sur le comportement à long terme de cavités souterraines dans la craie. PhD thesis, ENPC - France.

Oyama, T. \& Chigira, M. 2000. Weathering rate of mudstone and tuff on old unlined tunnel walls. Engineering Geology, 55(1-2), 15-27

Ratke, L. \& Vorhees, P.W. 2002. Growth and Coarsening. Ostwald Ripening in Material Processing. Heidelberg. Springer.

Risnes, R., Haghighi, H., Korsnes, R.1. \& Natvik, O. 2003. Chalk-fluid interactions with glycol and brines. Tectonophysics, 370: 213-226.

Risnes, R., Madland, M.V., Hole, M. \& Kwabiah, N.K. 2005. Water weakening of chalk - Mechanical effects of water-glycol mixtures. Journal of Petroleum Science and Engineering, 48: 21-36.

Robinson, D.A. \& Woodun, J.K. 2008. An experimental study of crust development on chalk download soils and their impact on runoff and erosion. European J. of Soil Science, 59: 784-798.

Schroeder, C. 2002. Du coccolithe au réservoir pétrolier: approche phénoménologique du comportement mécanique de la craie en vue de sa modélisation à différentes échelles. PhD thesis in Applied Sciences. University of Liège Belgium.

Schroeder, C. (Coordinator) 2003. Mechanical behaviour of partially and multiphase saturated chalks and fluid skeleton interaction: Main factor of chalk oil reservoirs compaction and related subsidence. Final report of the EU project (PASACHALK2).

Talesnick, M.L., Hatzor, Y.H. \& Tsesarsky, M. 2001. The elastic deformability and strength of a high porosity, anisotropic, chalk. International Journal for Rock Mechanics and Mining Sciences, 38: 543-555.

Voorhees, P.W. \& Glicksman, M.E. 1984. Solution to the multi-particle diffusion problem with applications to Ostwald ripening. Acta Metallurgica, 32(11): 2001-2030 